\title{
Effects of successive applications of maneb and benomyl on growth and yield of five wheat varieties of different heights
}

\section{J. H. J. Spiertz}

Department of Field Crops and Grassland Husbandry, Agricultural University, Wageningen, the Netherlands

Accepted: 16 June 1973

\section{Summary}

The effect of some fungicide treatments on the production pattern of five wheat varieties with different culm lengths was investigated in a field experiment. The fungicide treatments consisted of: a sequence of 2 pre-floral sprayings with $2 \mathrm{~kg}$ maneb per ha and 2 post-floral sprayings with $1 \mathrm{~kg}$ benlate per ha. The varieties were Juliana (117 $\mathrm{cm}$ culm length), Manella $(82 \mathrm{~cm})$, Lely, $(80 \mathrm{~cm})$, Mex.-cross $(69 \mathrm{~cm})$ and Gaines $(79$ $\mathrm{cm})$. There was hardly any mildew in the crop but Septoria tritici and Septoria nodorum were very much in evidence in all the varieties. Of the group of ripening diseases, black moulds and Fusarium were found to a lesser degree.

The combined application of maneb and benomyl greatly delayed the spread of Septoria in the crop, as a result of which the flag leaf in particular remained green for a longer period and the grain filling period was lengthened. The growth rate of the grains during the phase from the milk-ripe stage to the dough-ripe stage was raised from 204 $\mathrm{kg} \mathrm{ha}^{-1} \mathrm{day}^{-1}$ to $230 \mathrm{~kg} \mathrm{ha}^{-1} \mathrm{day}^{-1}$. The effect of the application was greater in the varieties most susceptible to Septoria (Lely and Gaines) than in the other varieties. The 1ncreases in grain yield of the varieties Juliana, Manella, Lely, Mex.-cross and Gaines were $14 \%, 23 \%, 32 \%, 16 \%$ and $42 \%$, respectively. By statistical analysis $85 \%$ of the variance in the grain yield within the varieties could be attributed to the green area of the flag leaf. Thus, the main effect of Septoria seems to be a reduction of the photosynthetic area, causing a decreased supply of assimilates to reach the grain, and in this way lowering the 1000 -grain weight.

The degree of disease infection was not significantly correlated with culm length of the amount of leaf area, so the tolerance and resistance characteristics of the varieties were not immediately due to differences in crop structure. Specific variety differences were still present, even after reduction of the disease infection with the fungicides.

\section{Introduction}

Cereal growers have always relied on breeding for resistance and on such methods as crop rotation, seed dressing, etc. for minimizing damage due to diseases. Owing to the increased disease intensity, which apparently is a consequence of narrower crop rotation and more intensive cultivation by using higher seed rates and more nitrogen fertilizer, the resistance of present-day wheat varieties to fungal diseases has in many cases proved inadequate (Dilz, 1970). Inadequate resistance is particularly evident in 
periods in which climatic conditions encourage the spread of moulds. Under such conditions the application of fungicides would seem worthwhile, particularly since, with the present high level of yields, a small effect will increase the yield enough to compensate for the cost of a fungicide dressing (de Jong, 1970).

Besides the effects of climate on the incidence of disease, is has been found (Feekes, 1967) that there is a great difference between the varieties with regard to their resistance to and tolerance of such diseases as Erysiphe graminis, Puccinia striiformis and Septoria norodum. Is is also assumed that culm length is an important feature for susceptibility to diseases; in this view varieties with short culms are more readily and seriously infected than those with longer culms (Brönnimann, 1969a). In the case of Septoria nodorum, this is supposed to be due to the shorter infection path from the soil via stem and leaf to the ear, or to the microclimate in crops with short culms being more favourable for fungi. Therefore the question arises whether varieties with greatly differing morphology differ in production owing to their variety-dependent susceptibility to diseases or owing to factors attributable to the physiology of growth. This should be tested by comparing crops with and without disease control by fungicides.

A field experiment was undertaken with five varieties of winter wheat to study the effect of fungal diseases on the production pattern of varieties with different crop morphologies. The crop was treated with two fungicides at different times before and after anthesis. The effect of leaf diseases, in particular on the size of the leaf area and on the grain filling process are studied in the light of the findings.

\section{Methods}

The experiment was carried out in 1972 on good clayey soil in the Flevo polder. The following varieties and crosses of winter wheat were used:

Dutch varieties:

Juliana - Wilhelmina $\times$ Essex gladkaf; crossed in 1903, 1921 accepted in Dutch variety list;

Manella - Alba $\times$ Heine's 7; crossed in 1950, 1964 variety list;

Lely - Cebeco $30 \times$ Flevina; crossed in 1960, 1970 variety list.

Semidwarfs:

Mex.-cross $-(\text { Nord } \times \text { Heine's 7) })_{103} \times$ Mex. dwarf; made available by Dr W. Feekes from Geertsema's Nurseries at Groningen;

Gaines $-($ Norin $10 \times$ Brevor, sel 14$) \times$ Brevor $\times$ Oro $\times$ Turkey $\times$ Florence $\times$ Oro $\times$ Fortyfold $\times$ Federation; crossed in Washington, USA, CI No 13448.

Sowing date: 15 October 1971; seed rate: $120 \mathrm{~kg}$ per ha. Fertilized in autumn with $60 \mathrm{~kg} \mathrm{P}_{2} \mathrm{O}_{5}$ superphosphate per ha. Potassium is abundant in this young marine clay, so no additional fertilizing was required. Two nitrogen dressings were given, viz $30 \mathrm{~kg}$ $\mathrm{N}$ per ha, as $\mathrm{Ca}\left(\mathrm{NO}_{3}\right)_{2}$ on $20 \mathrm{March}$, followed by a second dose of $30 \mathrm{~kg} \mathrm{~N}$ per ha on 4 May 1972.

Owing to the mild winter there was a good deal of chick-weed (Stellaria media) in April; this was controlled by spraying with 4 litres of MCPP and 4 litres MCPA per ha on 19 April. At the same time 3 litres of chlormequat per ha was sprayed on the crop.

Fungicides were applied according to the following scheme: 
Date Stage on

Feekes scale

(Large, 1954)

$\left.\begin{array}{l}15 \text { May } F_{7 \text { to } 8} \\ 29 \text { May } F_{9 \text { to } 10}\end{array}\right\}$ maneb
$\left.\begin{array}{l}20 \text { June } F_{10.3-10.5} \\ 11 \text { July idem }+ \\ 3 \text { weeks }\end{array}\right\}$ benlate
Preparation

name of agent

manganous ethylene-

-bis[dithiocarbamate]

benomyl: methyl-butyl

carbamoyl benzidiazolyl

carbamate

$\begin{array}{ll}\text { concen- } & \text { quantity } \\ \text { tration } & \text { of product }\end{array}$

$80 \%$ sol. $\quad 2 \mathrm{~kg} / \mathrm{ha}$

$50 \%$ sol. $\quad 1 \mathrm{~kg} / \mathrm{ha}$

Number of plots: 5 (varieties) $\times 2$ (Maneb + Benlate) $\times 6$ (replicates) $=60$.

The following intermediate harvests $(\mathrm{H})$ were carried out to determine the dry matter weights, the number of tillers and the green areas:

$\mathrm{H}_{1-4}$ : 10 March, 17 April, 2 May, 16 May; $0.25 \mathrm{~m}^{2}$ per variety;

$\mathrm{H}_{5}{ }_{9}$ : 30 May, 13 June, 27 June, 10 July, $25 \mathrm{July} ; 0.25 \mathrm{~m}^{2}$ of each plot;

$\mathrm{H}_{10}$ : 9 August; $1 \mathrm{~m}^{2}$ of each plot;

$\mathrm{H}_{11}$ : 21 August; $60 \mathrm{~m}^{2}$ harvested with the combine harvester.

The degree of disease infection in the field crop was estimated by rating on the harvesting dates $\mathrm{H}_{1-4}$; systematic estimates per leaf layer were made on 30 May, 7 June, 25 June and $10 \mathrm{July}$. On 20 July the leaf necrosis due to disease could no longer be clearly distinguished from normal dying off; therefore, only the percentage of green area of the flag leaf was ascertained on that date.

On 14 July the light interception at 3 heights in the crops was ascertained in all plots with the aid of an integrating photometer 1 metre long.

\section{Results}

\section{Degree of infection}

In 1972 the growing season was mainly dull, cold and wet, except for the second half of July, when there was a dry, sunny and extremely hot spell. Coming as it did after a mild winter, these weather conditions caused great disease intensity in the crop. Symptoms of the following diseases were determined:

at the base of culm: Cercosporella herpotrichoides

on leaf and ear : Septoria tritici

- eyespot

: Septoria nodorum

on the ear

: Fusarium sp.

- leaf blotch

- glume blotch

- fusarium

Cercosporella. On 15 June a test for soil-borne pathogens was carried out on 50 culms per plot. The degree of infection was calculated according to Fehrmann (1972) with the formula:

(\% slightly infected $+2 \times \%$ severely infected) $/ 100$

The indices (scale: $0-2$ ) thus calculated for Juliana, Manella, Lely, Mex.-cross and Gaines were $1.11,1.23,1.29,1.16$ and 0.95 , respectively. It is evident from these figures that all varieties were moderately infected with soil-borne pathogens, thus causing an 
increased risk of lodging. Lodging in all varieties with the exception of Juliana was presumably prevented by a relatively low nitrogen dressing and an early application of chlormequat.

Septoria. The severest leaf infection was by Septoria ( $S$. tritici and $S$. nodorum). By mid-May it was found that in all the varieties Septoria had covered the entire 5th leaf from the top and approximately $40 \%$ of the 4 th leaf. The first symptoms after anthesis were seen in the flag leaves in the untreated plots, whereas they did not appear in the plots treated with maneb and benomyl until a fortnight later. Early maneb sprayings followed by benomyl sprayings before and after anthesis dit not eradicate Septoria but cid largely inhibit its spread (Table 1). This is most evident from the green area of the flag leaf on 20 July, viz during grain growth.

Table 1. Infection in leaves and ears on $10 \mathrm{July}$ and green area of flag leaves and two topmost internodes on 20 July.

\begin{tabular}{|c|c|c|c|c|c|c|c|}
\hline & & \multicolumn{4}{|c|}{$\begin{array}{l}\text { \% of area covered with Septoria } \\
\text { symptoms on } 10 / 7\end{array}$} & \multicolumn{2}{|c|}{$\%$ of area green on $20 / 7$} \\
\hline & & $\begin{array}{l}\text { flag } \\
\text { leaf }\end{array}$ & $\begin{array}{l}\text { 2nd } \\
\text { leaf }\end{array}$ & $\begin{array}{l}\text { 3rd } \\
\text { leaf }\end{array}$ & ear ${ }^{1}$ & $\begin{array}{l}\text { flag } \\
\text { leaf }\end{array}$ & $\begin{array}{l}\text { 1st and } 2 \text { nd } \\
\text { internodes }\end{array}$ \\
\hline \multirow[t]{2}{*}{ Juliana } & + & 0.0 & 12.5 & 69.0 & 2.1 & 90.0 & 39.2 \\
\hline & 一 & 1.0 & 40.8 & 95.0 & 4.9 & 77.5 & 44.2 \\
\hline \multirow[t]{2}{*}{ Manella } & + & 0.7 & 7.5 & 72.5 & 11.8 & 93.3 & 17.5 \\
\hline & 一 & 5.0 & 60.9 & 99.2 & 23.6 & 32.5 & 27.5 \\
\hline \multirow[t]{2}{*}{ Lely } & + & 1.3 & 22.5 & 91.5 & 9.0 & 90.8 & 35.0 \\
\hline & - & 9.2 & 95.0 & 100.0 & 15.8 & 12.5 & 31.7 \\
\hline \multirow[t]{2}{*}{ Mex.-cross } & + & 0.0 & 1.5 & 24.2 & 22.9 & 84.2 & 20.0 \\
\hline & - & 1.8 & 10.8 & 74.2 & 34.1 & 40.0 & 13.3 \\
\hline \multirow[t]{2}{*}{ Gaines } & + & 1.2 & 68.2 & 100.0 & 17.9 & 64.2 & 15.8 \\
\hline & 一 & 55.0 & 100.0 & 100.0 & 25.2 & 5.0 & 12.5 \\
\hline \multirow[t]{2}{*}{ Average } & + & 0.6 & 22.4 & 71.4 & 12.7 & 84.5 & 21.3 \\
\hline & - & 14.4 & 61.3 & 93.7 & 20.7 & 33.3 & 21.5 \\
\hline
\end{tabular}

1 In the ear Septoria and Fusarium symptoms.

$\cdot+=2 \times$ maneb $+2 \times$ benlate; $-=$ untreated.

Fusarium. On 10 July a test for ear diseases was carried out on 20 ears per plot. The degree of infection by Septoria nodorum and $S$. tritici and by Fusarium culmorum is represented by one figure for both diseases (Table 1). Manella, Mex.-cross and Gaines were most susceptible to ear diseases. On average the ear infection was decreased by fungicides from 20.7 to $12.7 \%$.

The effect of the fungicide on green leaf area was found to be greatest in the varieties that were most severely infected with Septoria; the sequence from high to low was: Gaines, Lely, Manella, Mex.-cross and Juliana.

A point that should be noted is that the shortest and tallest variety were the least infected by Septoria; consequently, other variety characteristics besides the length of the culm must have affected resistance. 
The following diseases were also observed to a lesser degree of infection:

at the base of the culm : Gäummanomyces graminis _ take-all

on the leaf

: Erysiphe graminis

- mildew

in the ear (and on

: Puccinia recondita

- brown rust

some other parts

: Cladosporium sp.

: Alternaria sp.

- black moulds

of the culm)

\section{Effect of fungicides on production pattern}

From anthesis onwards, the areas of the separate leaves were measured. Significant $(\alpha<0.05)$ positive effects of maneb and benomyl on leaf area were observed in leaf (4) on 13 June, in leaf (4) and leaf (3) on 27 June, in leaf (3), leaf (2) and flag leaf on 10 July, and in the flag leaf on 25 July. The differences in leaf area observed on 13 and 27 June were the results of the two treatments with maneb on 15 and 29 May; they had no effect on the number of grains per ear (Table 2). In this experiment the indirect effect of maneb on grain filling by the longer protection of the two topmost leaves from Septoria could not be distinguished from the fungicidal action of benomyl sprayed on 20 June and 11 July. The observation that maneb only protects the leaf against fungal diseases for a limited time (approximately a fortnight), would imply that is was due to

a. LAI - flag leaf + second leof
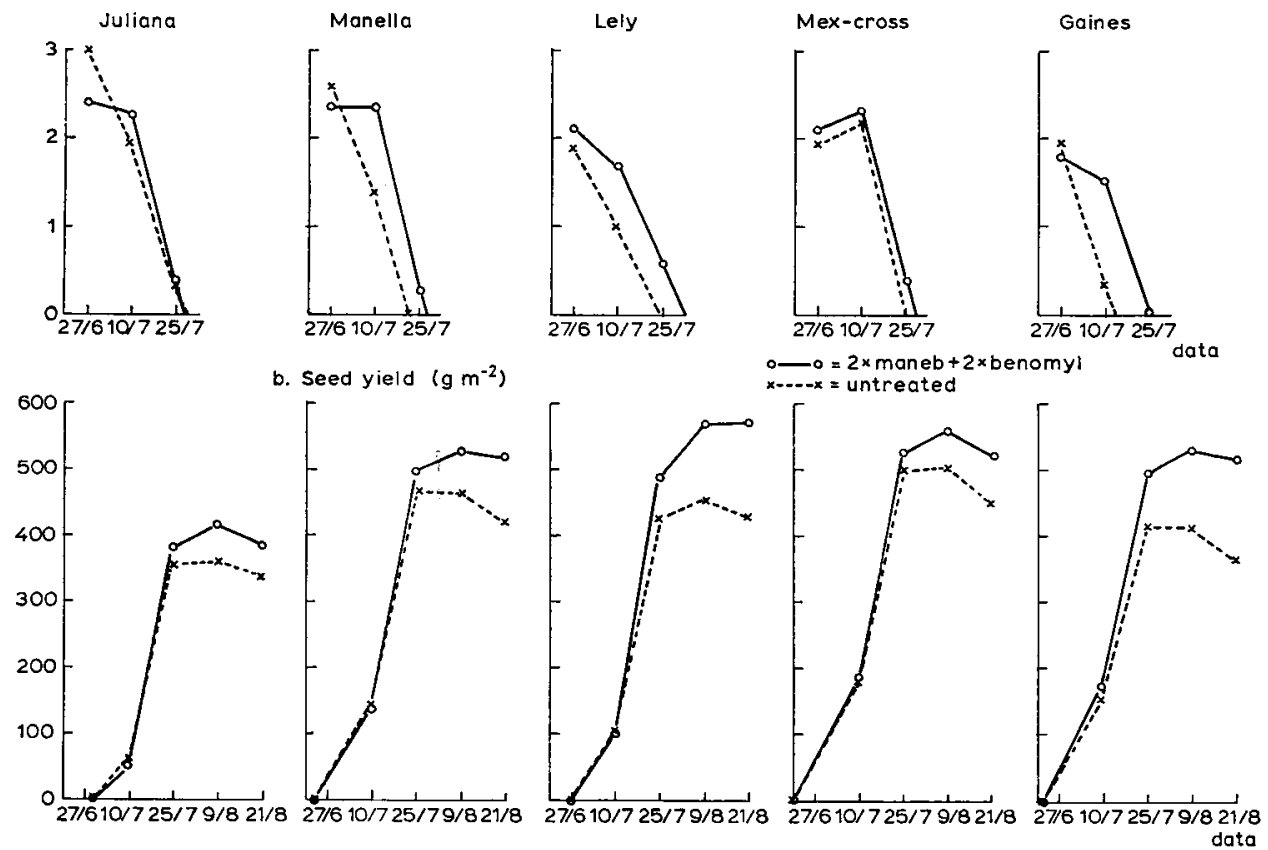

Fig. 1. Trend in the leaf area index of the flag leaf and second leaf (a) and in the seed yield (b) from flowering onwards with five varieties of wheat. 


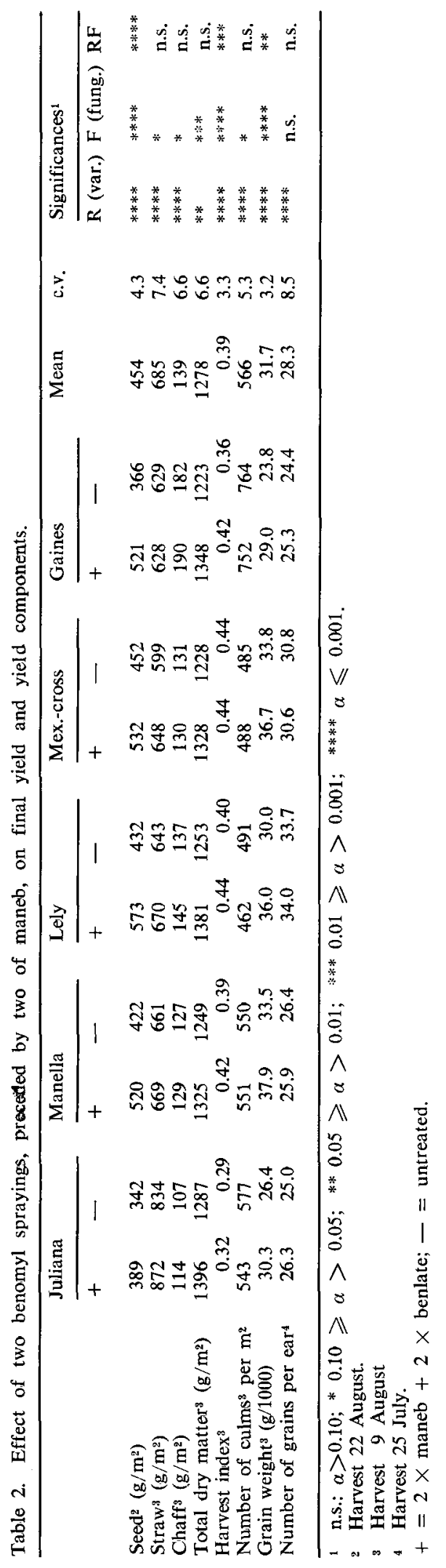


benomyl that the topmost leaves in the treated plots remained healthier during the grain filling period.

The curves in Fig. 1 show that the differences in leaf area index of the two topmost leaves correspond in magnitude to the differences between the grain yields of the treated and untreated plots. As the differences in grain weight did not occur until after $10 \mathrm{July}$, the size of the green area of the flag leaf in particular would appear to have been the determining factor, the more so since there were hardly any significant differences between the treated and untreated varieties in the green area of the leaf-sheath and the peduncle. The varieties with the greatest differences in area indices, viz Gaines, Lely and Manella, also show the greatest differences in grain yield.

The differences in grain yield came about in three phases:

1. Owing to be noticeable accelerated growth in the treated plots during the steep part of the growth curve in the period between 10 and 25 July (Table 3), the growth rate increased on average over the five varieties from 204 to $230 \mathrm{~kg}$ per ha per day.

2. During ripening, from 25 July to 9 August, the grain growth in the untreated plots came practically to a standstill, whereas in all the treated plots there was a further increase in grain weights.

3. A decrease of kernel weight in the untreated plots from 9 to 22 August, after the morphological maturity stage, owing perhaps to greater respiration losses in the untreated than in the treated plots. The differences between the colour of untreated crops and those treated with fungicides showed that there were great differences in infection with black moulds.

Statistical calculations (Table 2) showed that there were significant differences in the increase of grain yield of the five varieties owing to the application of maneb and benomyl. The absolute differences in seed yield for Juliana, Manella, Lely, Mex.-cross and Gaines were $+470,+980,+1410,+800$ and $+1550 \mathrm{~kg}$ of dry matter per ha, respectively. The straw yields were only noticeable higher in the Juliana, Lely and Mex.cross varieties, viz $+380,+270$ and $+490 \mathrm{~kg}$ of dry matter per ha, respectively. The relatively disproportionate increase in grain weight compared with straw weight was clearly expressed by the higher harvest indices for the Gaines and Lely varieties, which are very susceptible to Septoria; the increases due to maneb and benlate were from 0.36 to 0.42 and from 0.40 to 0.44 , respectively. Striking was that despite great differences in grain weight and straw weight there were only slight differences $(<5 \%)$ between the varieties with regard to their total dry matter yield above ground in both treated and untreated plots. These differences, in fact, are mainly the result of differences between the varieties with respect to distribution of the assimilates over grain and straw; this is particularly true of the Juliana variety.

On the yield components, i.e. number of culms per $\mathrm{m}^{2}, 1000$-grain weight and number of grains per ear, the 1000-grain weight was the most determinative for the differences in grain yield per ha. There was a slight negative fungicide effect on the number

Table 3. Growth rates of grain (kg ha-1 day-i) in the period from 10 to 25 July.

\begin{tabular}{lllllr}
\hline & Juliana & Manella & Lely & Mex.-cross & Gaines \\
& & & & & \\
Maneb + benomyl & 217 & 233 & 254 & 229 & 217 \\
Untreated & 198 & 215 & 215 & 214 & 176 \\
Difference & +19 & +18 & +39 & +15 & +41 \\
\hline
\end{tabular}


of culms per $\mathrm{m}^{2}$, resulting possibly from a phytotoxic action of maneb; there was no fungicide effect on the number of grains per ear. A very interesting point is that in the case of Lely and Mex.-cross a large number of grains per ear is accompanied by a high 1000 -grain weight, whereas in that of Juliana and Gaines the opposite is observed; Manella occupies an intermediate position with a low number of grains and a high 1000 -grain weight.

\section{Correlation and regression analysis}

To analyse the differences observed in grain yield, linear correlations between the grain yield in $\mathrm{g}$ per $\mathrm{m}^{2}$ and a number of crop parameters such as yield components, green area, degree of infection and light profile have been worked out.

Owing to the great differences between the varieties, the simple correlation have been calculated in three ways (see Table 4):

a) from the variance in $y$ and $x$ per variety;

b) from the variance in $y$ and $x$ within the five varieties;

c) from the variance in $y$ and $x$ between the five varieties.

The variance in $y$ and $x$ per variety and within the five varieties is mainly attributable to the effects of fungicides, whereas the variance between the five varieties is caused by varietal differences.

After elimination of the varietal differences, the grain yield showed a highly positive correlation with the 1000 -grain weight $(r=0.92)$; there was a high negative correlation with the degree of Septoria infection $(r=-0.88)$ in the topmost leaves, and with the Septoria and Fusarium infection in the ear $(\mathrm{r}=-0.50)$.

The effects of the Septoria infection were particularly evident from a reduction in the green area of the leaves, which resulted in a negative correlation $(r=-0.86)$ between the degree of Septoria infection in the period between 26 June and 10 July and the flag leaf green area percentage on $20 \mathrm{July}$. The relation between leaf infection and ear diseases was fairly weak $(r=0.36)$; this was due to an occurrence of Fusarium in the ear not directly associated with Septoria.

Correlations between grain yield and green leaf area were positive within the varieties and negative between them (see variables 5 to 9 in Table 4). The negative correlation is due to the combination of much leaf and a low grain yield in Juliana and of little leaf and a relatively high grain yield in Gaines, the other varieties occupying an intermediate position. Except in the case of Juliana, the correlation between grain yield and the leaf area of the topmost leaves was most significantly positive within the varieties and within each variety individually. The extreme differences between the Juliana and Gaines varieties also explain the negative correlation between grain yield and the green area of the internodes (see variable 10 in Table 4). A positive correlation within the varieties was expected for this interrelationship, but it did not come about, since in a few varieties the leaf sheaths remained green for a longer period in the plots in which the leaves died first because of the damage of Septoria.

Measuring the light interception at various heights in the crop, which was done only once on 14 July, gave a good picture of the differences between the varieties, but was too inaccurate to give a reliable explanation of differences due to Septoria infection (variables 13 and 14). A better idea of the effect of leaf diseases on the light distribution in the crop could be obtained by the erectness scores of the plants (variable 15); it should be noted that only Juliana lodged completely; the other varieties only drooped slightly during ripening. Within the varieties as well as between them the correlations 


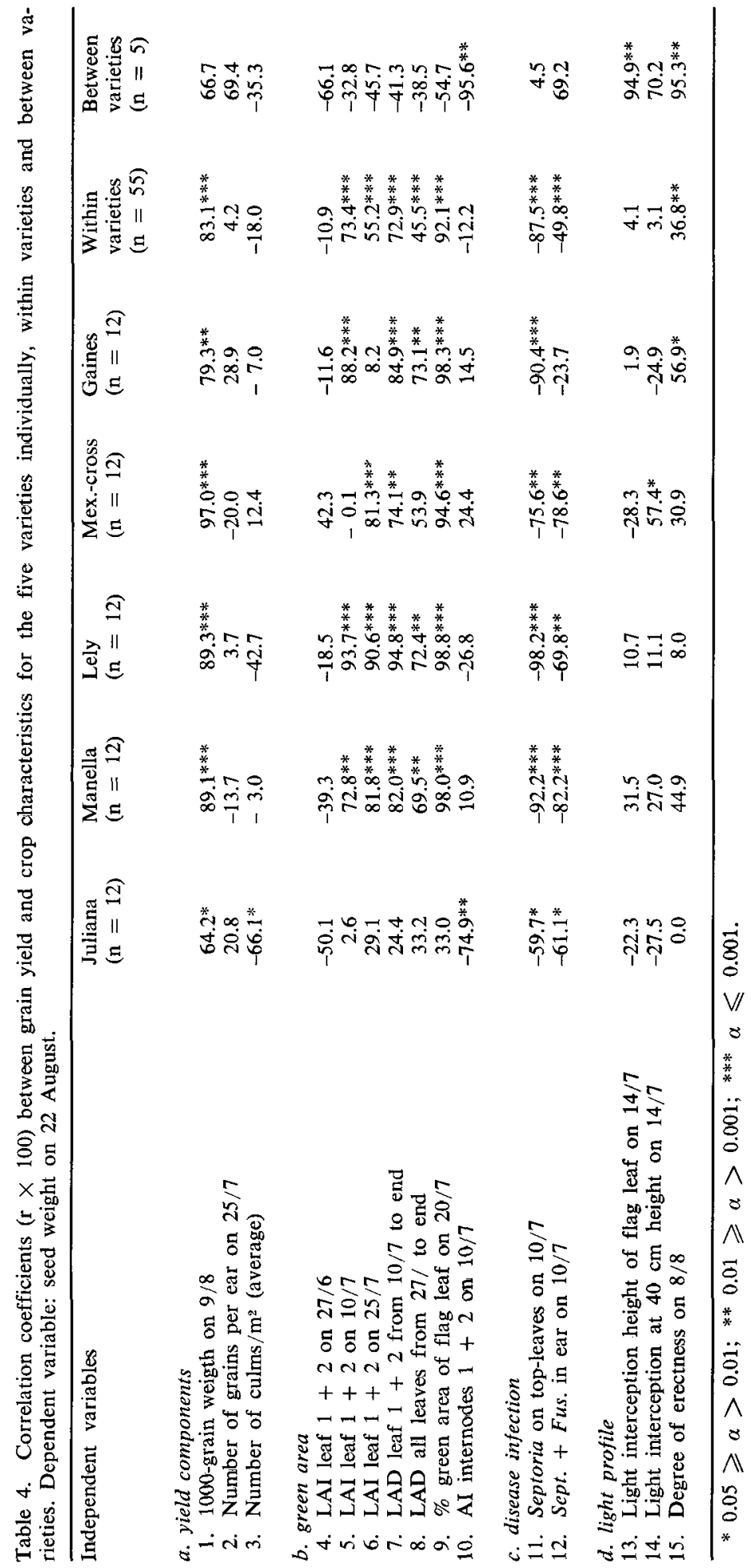


rable 5. Simple and multiple regression equations calculated from variance within the five varieties $(\mathrm{n}=55)$.

\begin{tabular}{|c|c|c|c|c|c|c|c|}
\hline Variablet & Mean & b & $\sigma_{\mathrm{b}}$ & $\begin{array}{l}\text { Student } \\
-\mathrm{t}\end{array}$ & Constant & $100 \mathrm{R} 2$ & c.v. $-\mathrm{y}$ \\
\hline$y=$ kernel yield & 453.8 & & & & & & 13.2 \\
\hline \multicolumn{8}{|c|}{ Simple regressions with $\mathrm{R}^{2}$ being $>0.50$} \\
\hline $\mathrm{x}_{1}=\begin{array}{l}1000-\text { kernel } \\
\text { weight }\end{array}$ & 31.7 & 17.9 & \pm 1.6 & 11.0 & -115.9 & 69.1 & 7.4 \\
\hline $\begin{aligned} x_{5}= & \text { LAI leaf } 1+2 \\
& \text { on } 10 / 7\end{aligned}$ & 2.0 & 103.0 & \pm 13.0 & 7.9 & 246.4 & 53.9 & 9.1 \\
\hline $\begin{aligned} x_{7}= & \text { LAD leaf } 1+2 \\
& \text { from } 10 / 7 \text { to end }\end{aligned}$ & 2.7 & 50.7 & \pm 9.2 & 5.5 & 136.9 & 53.1 & 9.2 \\
\hline $\begin{aligned} \mathrm{xg}= & \% \text { green area } \\
& \text { flag on } 20 / 7\end{aligned}$ & 59.0 & 1.9 & \pm 0.1 & 17.4 & 343.1 & 84.8 & 5.2 \\
\hline $\begin{aligned} \mathrm{x}_{11}= & \% \text { Septoria on } \\
& \text { leaves } 1+2 \\
& \text { on } 10 / 7\end{aligned}$ & 33.2 & -1.5 & \pm 0.1 & 14.9 & 503.6 & 76.6 & 6.3 \\
\hline
\end{tabular}

Multiple regression, with $9 \mathrm{x}$-variables in the sequence: $\mathrm{x}_{9}, \mathrm{x}_{7}, \mathrm{x}_{10}, \mathrm{x}_{11}, \mathrm{x}_{12}, \mathrm{x}_{15}, \mathrm{x}_{13}, \mathrm{x}_{3}$ and $\mathrm{x}_{2}$. The only $x$-variables included in the equation are those whose $t 0.05$ value of the regression coefficient was greater than 1.96 .

\begin{tabular}{|c|c|c|c|c|c|c|c|}
\hline $\mathbf{X}_{9}$ & $\begin{array}{c}=\% \text { green flag } \\
\text { leaf on } 20 / 7\end{array}$ & 59.0 & 1.2 & \pm 0.2 & 7.3 & & $(84.8)$ \\
\hline $\mathbf{X}_{10}$ & $\begin{aligned}= & \text { AI internodes } \\
& 1+2 \text { on } 10 / 7\end{aligned}$ & 0.4 & -317.2 & \pm 85.0 & 3.7 & & $(86.7)$ \\
\hline$x_{11}$ & $\begin{array}{l}=\% \text { Septoria on } \\
\text { leaves } 1+2 \\
\quad \text { on } 10 / 7\end{array}$ & 33.2 & -1.2 & \pm 0.2 & 5.5 & & $(90.8)$ \\
\hline $\mathbf{x}_{3}$ & $=\underset{\text { per } \mathrm{m}^{2}}{\text { number of culms }}$ & 566.2 & 0.2 & \pm 0.1 & 2.6 & 420.2 & 91.9 \\
\hline
\end{tabular}

1 The coding of the $x$-variables tallies with the coding of Table 4.

between grain yield and a high erectness score were significantly positive, the correlation being 36.8 and 95.3 , respectively.

The correlations between 1000-grain weight and the variables in Table 4 were of the same order of magnitude as for grain yield.

Quantification of the correlations between grain yield and crop parameters by means of simple and multiple regression calculations is of relatively little value because the explanatory variables are not all independent and the causality of the correlations is only partly known. For these reasons only the most reliable and informative regression equations are given in Table 5.

The simple linear regression equations bring out once again the close correlation between grain yield and the parameters for the green area of the flag leaf. To illustrate this, Fig. 2 sets out the correlation between grain yield and green area, both expressed in relative values so as to eliminate differences in the levels of varieties.

The multiple regression analysis with the yield components as variables left $30 \%$ of the variance in grain yield unaccounted for; the number of grains per ear and the number of ears per $\mathrm{m}^{2}$ did not help to clarify the position. A regression analysis with 9 variables, including yield components, morphological characteristics and crop traits, 


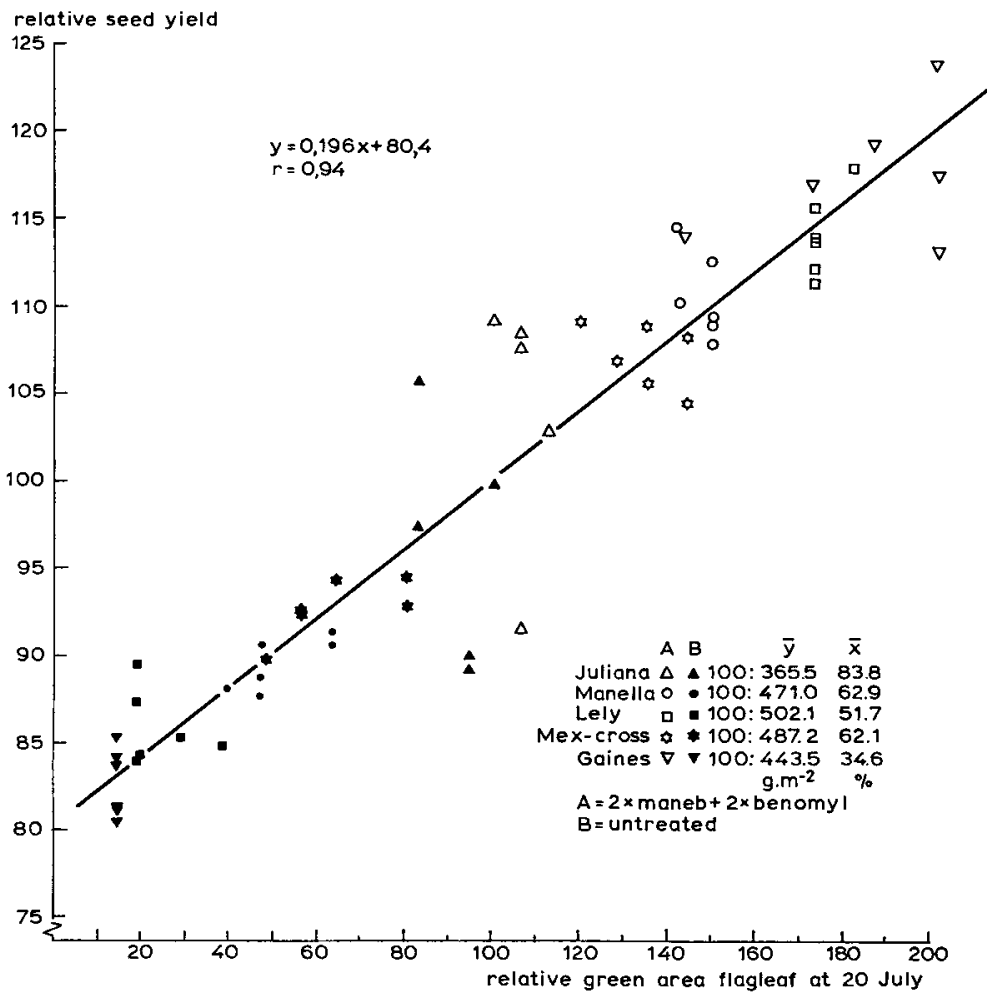

Fig. 2. Relation between the relative seed yield at harvest and the relative green area of the flag leaf at 20 July. For each variety the means of the $x$ and $y$ variables are fixed at 100 .

resulted in a formula with 4 variables which together accounted for approximately $92 \%$ of the original variance in grain yields (Table 5). The green area of the flag leaf constituted the major proportion $(85 \%)$. This parameter also largely represents the remaining green area of the second leaf and the ear. The Septoria infection mainly affected the grain weigth and grain yield by reducing the photosynthetic leaf area, in addition it had an effect of its own of approximately $4 \%$.

\section{Uptake of nitrogen}

The nitrogen content of the seed on 25 July (dough-ripe) was clearly lower in the plots treated with fungicides $(1.68 \%$ as against $1.84 \%)$ but in the total culm the differences vere slighter $(0.91 \%$ as against $0.97 \%)$. The differences must be the result of a more rapid grain growth in the plots treated with fungicides, as the quantities of nitrogen taken up in the culm did not differ. The content therefore declines as a result of a dilutent effect.

In the period between 25 July and the final harvest on 22 August the nitrogen content of the seed was found to have increased in both untreated and treated plots; the content was $1.86 \%$ and $1.95 \%$ nitrogen, respectively. The quantity of nitrogen in the 

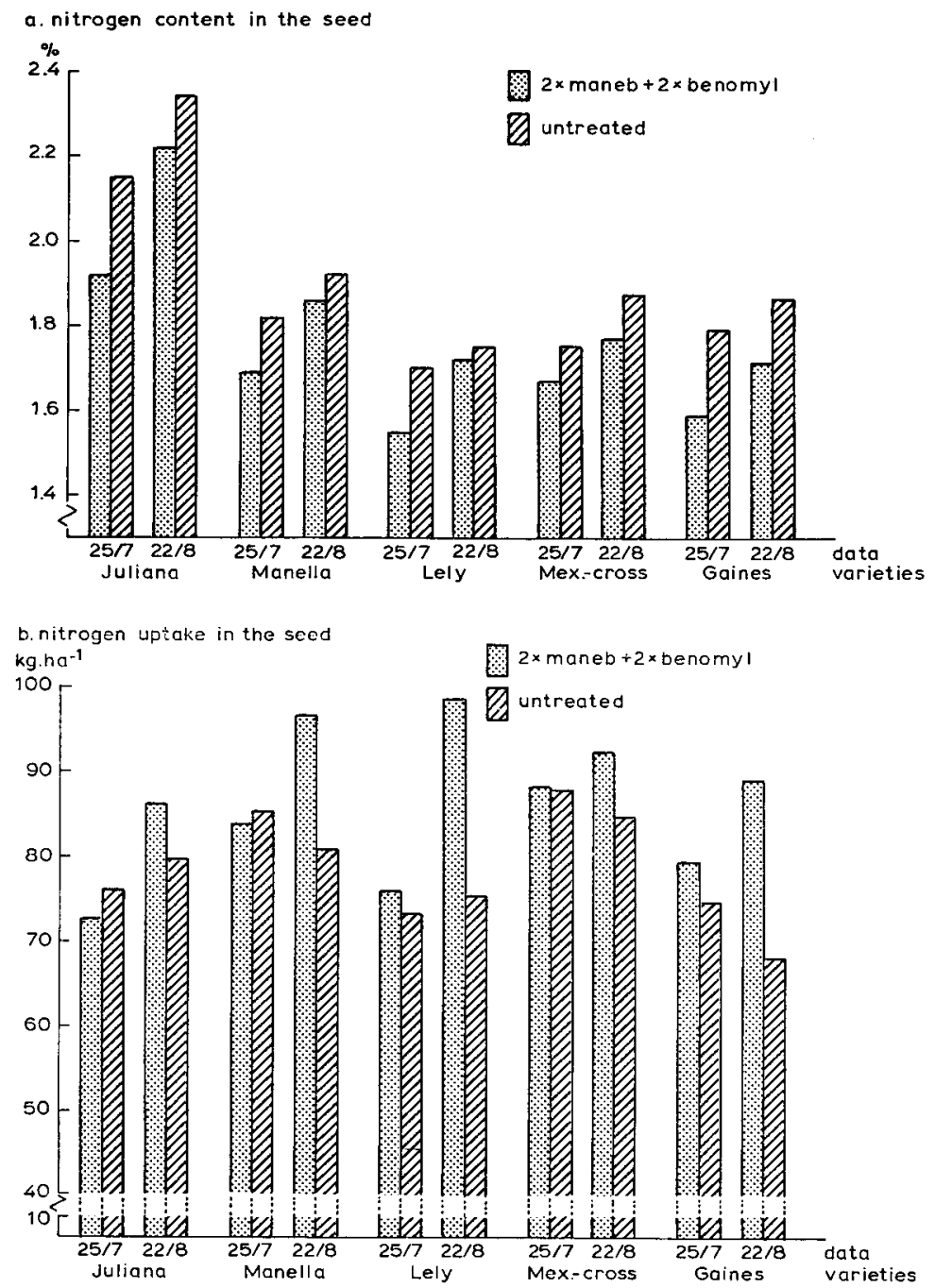

Fig. 3. The nitrogen content (a) and the nitrogen uptake (b) in the seed by five wheat varieties at two harvest data, 25 July and 22 August, for the untreated and the fungicides plots.

treated plots had risen noticeably owing to the increased nitrogen content of the seed and the increased grain weight, resulting in differences of $+7.6 \%,+19.7 \%,+32.0 \%$, $+9.5 \%$ and $+30.5 \%$ for the Juliana, Manella, Lely, Mex.-cross and Gaines varieties, respectively, compared with the untreated plots. The nitrogen content and the quantity of nitrogen taken up in the seed also varied greatly from variety to variety (Fig. 3A and 3B). A high $\mathrm{N}$ content in the Juliana variety did not correspond with a high uptake whereas the highest yield of nitrogen was found in the seed of Lely, which had a relatively low nitrogen content. It was impossible to establish whether the increase in 
the quantity of nitrogen in the seed in the plots treated with fungicides was the result of retranslocation from leaf and stem or direct uptake from the soil via the roots, because no analysis were carried out on the straw at the final harvest.

\section{Discussion}

The incidence of fungal diseases is dependent to a high degree on climatic conditions. According to Brönnimann (1968) the principal disease in this experiment, Septoria no«orum and $S$. tritici occur regularly in regions with high precipitation. Van der Wal (pers. commun. 1972) states that a relatively low temperature and a long wet-leaf period in particular promote the spread of Septoria. The weather factors in the 1972 growing season provided these conditions.

The differences observed between the five varieties with regard to disease occurrence are not the direct consequence of morphological differences, because the shortest and the tallest variety were the least diseased and the varieties with the lowest leaf area index were most heavily infected. It cannot be denied, however, that the morphology of a crop can affect the microclimate and consequently also the amount of infection within a variety.

To control as wide a spectrum of fungal diseases as possible, one systematic preparation (benomyl) and one non-systematic (maneb) were used. Bouchet et al. (1972) obtained better results with a combination of fungicides than with single fungicides. In their experiments the extra yields of winter wheat ranged from $4 \%$ to $21.7 \%$ in 1970 and from $3.7 \%$ to $56.3 \%$ in 1971 . The results depended very much indeed on the combination used and the moment at which the dressing is applied.

Although Septoria does not usually occur in the grain-producing organs until late in the growing season, it can do considerably damage. Shipton (1968) quotes from the relevant literature yield losses of $28 \%$ and extreme values up to $95 \%$ for $S$. tritici and $S$. nodorum, respectively, after natural infection; the damage done by $S$. tritici might increase to $45 \%$ by artificial inoculation. Although the plots treated with benomyl and maneb in our own experiment were not free from disease, there were extra yields of $13.8 \%, 23.4 \%, 32.3 \%, 15.6 \%$ and $42.1 \%$ for Juliana, Manella, Lely, Mex.-cross and Gaines, respectively, compared with the untreated plots. It should be noted that even after treatment with fungicides the yield this year fell far short of the potential level in the Netherlands.

By statistical analysis $69 \%$ of the variance in grain yield was attributable to the 1000 grain weight; the number of grains per ear was scarcely affected by fungicide treatment. Similar results were obtained by Brönnimann (1972) and Dilz \& Schepers (1972).

Brönnimann (1969) noted yield losses after the infection of separate organs with $S$. nodorum, $40.6 \%, 45.7 \%, 14.8 \%$ and $1.1 \%$ of which were caused by the ear, the flag leaf, leaf 2 and leaf 3, respectively. He suggested that besides damage to the assimilative tissue there is also disturbance of the translocation of the assimilates to the grains. Our own findings concerning the relationship between the green area of the flag leaf and the kernel yield $\left(R^{2}=0.85\right)$ stress the importance of keeping the flag leaf healthy. The co-variance between infections with leaf and ear diseases was only 0.36 . The flag leaf's function of supplying assimilates to the growing grain was also confirmed repeatedly by ${ }^{14} \mathrm{C}$ tests (Rawson \& Hofstra, 1969, and others). The multiple correlation and regression calculation showed that all but $4 \%$ of the total effect of Septoria on the variance in grain yield was attributable to a change in the assimilative area. 
Fusarium and black moulds as well as Septoria occurred in the ear during ripening. The latter group in particular appeared to be considerably inhibited by benomyl. The very slight weight losses in the treated compared with the untreated plots in the period from 9 to 22 August were possibly due to benomyl.

It is known that benomyl is also active against Cercosporella herpotrichoides (Fehrmann, 1972). There are one or two indications that even late applications of benomyl (before and after anthesis) reduced somewhat the fairly high degree of infection by soil-borne pathogens, since the culms in the treated plots, wit the exception of Juliana, drooped less than in the untreated ones. At the same time the uptake of nitrogen by the seed in the period from 25 July to 22 August averaged $14 \%$ in the plots treated with fungicide, whereas there was no further uptake in the untreated plots. This indicates greater root activity in the treated plots, since in the Lely variety in particular the $25 \mathrm{~kg}$ increase of nitrogen in the seed is to great to have become available merely from the $49 \mathrm{~kg}$ store in the straw at $25 \mathrm{July}$.

It may be concluded that the control of fungal diseases in wheat varieties with maneb and benomyl in crops with differing crop structure and disease susceptibility in each case resulted in an increase in the grain yield or straw yield. The higher grain yield in this experiment was brought about mainly by the flag leaf and other assimilative organs remaining green for a longer period, so that in the last fortnight of grain filling there were marked differences between the treated and the untreated plots. Quantitatively, the effect of treatment was greatest in the varieties most sensitive to Septoria, viz Lely and Gaines. Characteristic differences between the varieties even remained after the inhibition of several fungal diseases, particularly with regard to their dry matter distribution (harvest index) and the uptake of nitrogen in the above-ground parts.

\section{Acknowledgments}

This study was carried out in consultation with Ir L. J. P. Kupers and various colleagues, to whom I wish to express my gratitude for their interest. Thanks are esspecially due to $\mathrm{Mr}$ J. Ellen for skilful assistance and to Mr J. B. Lettinga and co-workers for careful execution of the various treatments.

\section{References}

Bouchet, F. et al., 1972. Lutte contre les maladies des céréales par traitement des organes aériens. Phytiatrie-Phytopharmacie, numéro spécial: $25-36$.

Brönnimann, A., 1968. Probleme der Weizenzüchtung auf Septoria-Verträglichkeit. Arbeitstagung 1968, Gumpenstein.

Brönnimann, A., 1969a. Einfluss einer züchterisch oder durch Chlorocholinchlorid bedingten Halmverkürzung bei Sommerweizen auf den Befall und die Schädigung durch Septoria nodorum Berk. . Z. Acker- u. Pfl.Bau 129: 247-258.

Brönnimann, A., 1969b. Ursachen der unterschiedlichen Verträglichkeit des Weizens gegenüber Befall durch Septoria nodorum Berk. Phytopathology 66 (2): 353-364.

Brönnimann, A., W. Künzli \& F. Häni, 1972. Reaktionen einiger Weizensorten auf Septoria Befall nach CCC-Behandlung. Mitt. Schweiz. Landw. 20 (8) 141-150.

Dilz, K., 1970. De stikstofbemesting van granen (The nitrogen fertilization of cereals). 21. Effect van ziektebestrijding op de stikstofreactie van zomertarwe met en zonder toepassing van CCC (Effect of disease control on the nitrogen reaction of summer wheat, with and without CCC). Stikstof 6: $65,185-188$

Dilz, K. \& J. H. Schepers, 1972. Stikstofbemesting van granen (Nitrogen fertilization of cereals). 24. Effect van ziektebestrijding op de stikstofreactie van winter-, zomertarwe en haver met en zonder 
toepassing van $\mathrm{CCC}$ (Effect of disease control on the nitrogen reaction of winter and summer wheat and oats, with and without (CC). Stikstof 6: 452-458.

Feekes, W., 1967. Phytopathological consequences of changing agricultural methods. II. Cereals. Neth. J. Pl. Path. 73: 97-115.

Fehrmann, H. \& H. Schrödter, 1972. Ökologische Untersuchungen zur Epidemiologie von Cercosporella herpotrichoides. IV. Erarbeitung eines praxisnahen Verfahrens zur Bekämpfung der Halmbruchkrankheit des Weizens mit systemischen Fungiciden. Phytopathology 74 (2) 161-174. Jong, G. J. de, 1970. Behandeling van wintertarwe met fungiciden. Stikstof 6: 189-191.

Large, E. C., 1954. Growth stages in cereals. Illustration of the Feekes scale. Pl. Path. 3: 128-139.

Rawson, H. M. \& G. Hofstra, 1969. Translocation and remobilization of ${ }^{14} \mathrm{C}$ assimilated at different stages by each leaf of the wheat plant. Aust. J. biol. Sci. 22: 321-331.

Shipton, W. A., 1968. The effect of Septoria diseases on wheat. Aust. J, exp. Agric. Anim, Husb. 8: 89-93. 